\section{Landscape Performance and Fruiting of Nine Heavenly Bamboo Selections Grown in Northern and Southern Florida}

\author{
Sandra B. Wilson ${ }^{1}$ \\ Department of Environmental Horticulture, University of Florida, Institute of \\ Food and Agricultural Sciences, Gainesville, FL 32611; and the Indian River \\ Research and Education Center, 2199 South Rock Road, Fort Pierce, FL 34945 \\ Gary W. Knox \\ Department of Environmental Horticulture, University of Florida, Institute of \\ Food and Agricultural Sciences, Gainesville, FL 32611; and North Florida \\ Research and Education Center, 155 Research Road, Quincy, FL 32351
}

\section{Zhanao Deng}

Department of Environmental Horticulture, University of Florida, Institute of Food and Agricultural Sciences, Gainesville, FL 32611; and GulfCoast Research and Education Center, 14625 County Road 672, Wimauma, FL 33598

\section{Keona L. Nolan}

Department of Environmental Horticulture, University of Florida, Institute of Food and Agricultural Sciences, Gainesville, FL 32611; and the Indian River Research and Education Center, 2199 South Rock Road, Fort Pierce, FL 34945

\section{James Aldrich}

Department of Environmental Horticulture, University of Florida, Institute of Food and Agricultural Sciences, Gainesville, FL 32611; and the North Florida Research and Education Center, 155 Research Road, Quincy, FL 32351

Additional index words. cultivar trialing, invasive plants, Nandina domestica, seed germination, woody shrubs

\begin{abstract}
A wild-type selection of heavenly bamboo (Nandina domestica) and eight cultivars were evaluated in northern and southern Florida for 144 weeks. Onset of flowering generally began by April and May in southern Florida and 4 to 8 weeks later in northern Florida. Fruit was first noted 4 to 8 weeks after most cultivars began flowering. Landscape performance and fruit production varied widely among taxa and location. 'AKA', 'Firehouse', 'Firepower', and 'Firestorm' heavenly bamboo did not flower or fruit in either location. Greater plant growth, survival, and fruiting were observed in northern Florida than in southern Florida. In both locations, the wild-type form of heavenly bamboo produced more fruit than 'Alba', 'Gulf Stream', 'Monfar', and 'Moyer's Red'. Seed viability was fairly consistent among fruiting cultivars, ranging from $69 \%$ to $89 \%$. Nuclear DNA content and ploidy analysis indicated that all nine nandina cultivars were diploids, suggesting that tetraploidy is not the genetic cause of the non-fruiting trait in 'AKA', 'Firehouse', 'Firepower', and 'Firestorm'. Results of this study offer insight into future non-invasive heavenly bamboo breeding efforts and emphasize the importance of cultivar and geographic distinctions when regarding the invasive status of a species.
\end{abstract}

Received for publication 24 Feb. 2014. Accepted for publication 29 Apr. 2014.

We acknowledge partial financial support from the Florida Fish and Wildlife Conservation Commission and the Center for Applied Nursery Research. We extend gratitude to Patricia Frey and Katelyn Stassi for providing field and technical assistance throughout the study. We thank Dr. Jaroslav Doležel (Laboratory of Molecular Cytogenetics and Cytometry, Institute of Experimental Botany, Olomouc, Czech Republic) for providing cereal rye seeds that were used as the reference for flow cytometry work in this study and Zhe Cao and Alison Yang for performing the flow cytometry analysis at the University of Florida Interdisciplinary Center for Biotechnology Research's Flow Cytometry Core Laboratory in Gainesville, FL. ${ }^{1}$ To whom reprint requests should be addressed; e-mail sbwilson@ufl.edu. plants were marketed (Pemberton and Liu, 2009).

In Florida, significant controversy surrounds the current invasive status of a popular ornamental shrub, heavenly bamboo (Nandina domestica). Native to forest understories of central China and Japan and west to India and introduced to the United States before 1804 (Langeland et al., 2008), the species has escaped cultivation in nine states in the southeastern United States [U.S. Department of Agriculture (USDA), 2013], including Florida (eight counties) (Wunderlin and Hansen, 2008). The Florida Exotic Pest Plant Council (FLEPPC) lists heavenly bamboo as a Category I invasive species because it is ecologically damaging to natural areas (FLEPPC, 2013). Self-sustaining and expanding populations of heavenly bamboo have been found in natural plant communities of northern and central Florida where it is altering the light environment (Cherry, 2002) and displacing native vegetation (Langeland et al., 2008). Consequently, The University of Florida (UF) Institute of Food and Agricultural Sciences (IFAS) Status Assessment does not recommend its planting in northern Florida (area annually receiving 420 or more chill units) and central Florida (area receiving more than 110 but fewer than 420 chill units) and recommends caution if planting in southern Florida (receiving 110 or fewer chill units) (IFAS Invasive Plant Working Group, 2013). All cultivars fall under this recommendation, unless subjected and approved as noninvasive by the UF Infraspecific Taxon Protocol. To date, only three cultivars have been designated noninvasive and approved for use in Florida, 'Harbour Dwarf' (Knox and Wilson, 2010), 'Firepower' (Knox and Wilson, 2009), and 'Gulf Stream' (IFAS Invasive Plant Working Group, 2013).

The wild-type form of Nandina domestica is adapted to conditions ranging from full sun to shade and moist to dry soils in USDA hardiness zones 6 to 10 (Dirr, 1998). The species is variably rhizomatous depending on the clone and is characterized by tripinnately compound leaves that are dark green turning blush to reddish purple with the onset of low temperatures. Terminal panicles of white flowers appear in mid- to late spring and are followed in summer and fall by red fruit, each containing between one and four seeds; however, one or two seeds is most common. The ornamental characteristics, tolerance to pruning, resistance to disease, and adaptability of heavenly bamboo make it an extremely popular landscape plant. A Florida study documented the plant's ornamental importance, reporting that heavenly bamboo was grown by $14.9 \%$ of the responding nurseries with estimated statewide total sales of $\$ 3.3$ million in 2003 (Wirth et al., 2004).

Over 40 different heavenly bamboo cultivars are commercially available in the United States (Dirr, 1998; Gilman, 1999; Raulston, 1984; Roethling et al., 2003) but limited information is available in reference to their potential invasiveness. Knox and Wilson (2006) evaluated 10 heavenly bamboo cultivars and reported above average visual quality 
rankings, good survival, and limited or lacking fruit production of 'Gulf Stream', 'Jaytee', and 'Harbour Dwarf' warranting wider landscape use of these selections in the Florida landscape. The overall objective of this study was to evaluate the plant performance, growth, flowering, fruit production, seed viability, and ploidy level of the wildtype and eight additional new heavenly bamboo cultivars planted in southern Florida (Fort Pierce, USDA plant hardiness zone 9b) and northern Florida (Quincy, USDA hardiness zone 8b) (USDA, 2012).

\section{Materials and Methods}

Plant material and field conditions. Nine heavenly bamboo selections were chosen for this study based on availability and landscape industry use (Table 1). All selections were obtained as plugs or finished 3.8-L or 11.4-L plants from commercial nurseries; plugs were transplanted into 3.8-L containers and finished at the North Florida Research and Education Center in Quincy (Table 1). Before planting, beds were prepared by applying glyphosate herbicide (Roundup; Monsanto Co., St. Louis, MO) and slightly disking before covering with black semipermeable landscape fabric (Lumite Inc., Baldwin, GA). On 6 May 2008, six uniform plants of 'Alba' and nine uniform plants of the other heavenly bamboo selections were spaced $1.2 \mathrm{~m}$ on center under full sun conditions in two locations: southern Florida (Fort Pierce) and northern Florida (Quincy). Plants were subirrigated by filling canals (southern Florida) or drip-irrigated (northern Florida) as needed (up to three times per week). Plants were fertilized at Weeks 19,49 , and 62 with $24 \mathrm{~g}$ of $15 \mathrm{~N}-3.9 \mathrm{P}-10 \mathrm{~K}$ controlled-release fertilizer (Osmocote Plus; Scotts, Marysville, $\mathrm{OH})$ in the area 15 to $30 \mathrm{~cm}$ from the crown. Plants were fertilized again at Weeks 105 and 126 with an additional $27.8 \mathrm{~g}$ (medium-sized cultivars) and $31.5 \mathrm{~g}$ (tall-sized cultivars) of fertilizer, respectively. Daily rainfall, temperature, and relative humidity were recorded by Florida Automated Weather Network monitoring stations located at each site (Fig. 1) and presented as monthly averages. Field conditions for southern Florida were as follows: Ankona sand with $0.8 \%$ organic matter, $\mathrm{pH}$ 6.8 , average monthly rainfall $10.2 \mathrm{~cm}$, mean minimum and maximum temperatures 9.4 and $32.3{ }^{\circ} \mathrm{C}$, respectively, and $79 \%$ relative humidity. Field conditions for northern Florida were as follows: Tifton loamy fine sand with $2.6 \%$ organic matter, $\mathrm{pH} 4.7$, average monthly rainfall $12.0 \mathrm{~cm}$, mean minimum and maximum temperatures 5.1 and $31.0^{\circ} \mathrm{C}$, respectively, and $78 \%$ relative humidity.

Visual quality, flowering, and plant growth. Visual quality (plant color and form) was assessed every 12 weeks for each cultivar independently at each location. Assessments of foliage color and form were performed on a scale from 1 to 5 where 1 = very poor quality, not acceptable, severe leaf necrosis or chlorosis, not marketable; 2 = poor quality, not acceptable, large areas of necrosis or chlorosis, poor form, not marketable; 3 = fair quality, somewhat desirable form and color, fairly marketable; 4 = good quality, very acceptable and desirable color and form without chlorosis, marketable; and $5=$ excellent quality, perfect condition, premium color and form, very marketable.

Observations of flower initiation, flowering period, and fruit formation were recorded every 4 weeks. Before fruit maturity, mesh netting was placed over panicles or entire plants to prevent predation. Mature fruit was manually collected and counted at each location in mid-November to early Dec. 2010 (Quincy, Week 137 and Fort Pierce, Week 140). Growth data were recorded for each plant at both sites at the beginning (Week 0) and end of the experiment (Week 144). Growth indices were calculated as an average of the measured height (measured from crown to natural break in foliage) and two perpendicular widths [(width1 + width2)/2].

Seed germination and viability. Mature fruit were removed from plants and depulped by hand using a dehulling trough (Hoffman Manufacturing, Inc., Albany, OR). Immature seeds or seeds with visible indication of pathogen or insect damage were discarded. Cleaned seeds were gravity air-dried at $22{ }^{\circ} \mathrm{C}$ for 48 to $72 \mathrm{~h}$ before analysis. In accordance with the Tetrazolium Testing Handbook, Contribution No. 29 Association of Official Seed Analysts rules (Peters, 2000), viability tests were replicated twice on a subset of 100 seeds per species from fresh seed collected in northern Florida. Seeds were pre-treated by allowing them to imbibe by soaking in water overnight at room temperature. Seeds were then cut longitudinally completely through the seed keeping half and stained overnight at 30 to $35{ }^{\circ} \mathrm{C}$ in $1.0 \%$ tetrazolium $(2,3,5$ triphenyl chloride) solution with positive staining patterns confirming seed viability (Mid-West Seed Service Inc., Brookings, SD). An additional 400 seeds per cultivar from northern Florida were subjected to germination tests (four replications of 100 seeds per test) with an 8 -h photoperiod at a temperature of $30^{\circ} \mathrm{C}$ followed by $16-\mathrm{h}$ darkness at $20{ }^{\circ} \mathrm{C}$ (Mid-West Seed Service Inc.). Seeds were arranged in germination boxes (containing two sheets of blotter paper) and placed in incubators equipped with cool-white fluorescent lamps. Final germination readings were taken at Day 60. Ungerminated seed were subjected to post-germination viability tests (as described previously) and used to report percent dormancy.

Nuclear DNA content and ploidy level. Mature leaves were collected from heavenly bamboo plants ( 1 to 5 years old) grown in northern Florida, southern Florida, or southwestern Florida (Wimauma), and all were shipped to the UF Gulf Coast Research and Education Center (Wimauma). Flow cytometry was performed as described by Doležel et al. (2007) at the UF/Interdisciplinary Center for Biotechnology Research's Flow Cytometry Core Laboratory in Gainesville, FL, to determine the nuclear DNA content and ploidy level of heavenly bamboo cultivars. Leaf tissue $(\approx 20 \mathrm{mg}$ ) was chopped in the
LB01 nuclei isolation buffer using a sharp razor blade, the released nuclei were stained with propidium iodide $\left(50 \mu \mathrm{g} \cdot \mathrm{mL}^{-1}\right)$, the resultant nuclear suspension was filtered through, and the isolated nuclei were analyzed on a personal cytometer (Model Accuri C6; BD Biosciences, San Jose, CA) for fluorescence intensity. The LB01 buffer was prepared as described by Doležel et al (2007), containing $15 \mathrm{~mm}$ Tris, $2 \mathrm{~mm}$ $\mathrm{Na}_{2}$ EDTA, $0.5 \mathrm{~mm}$ spermine tetrahydrochloride, $80 \mathrm{~mm} \mathrm{KCl}, 20 \mathrm{~mm} \mathrm{NaCl}, 0.1 \%$ (v/v) Triton X-100, and adjusted to $\mathrm{pH} 7.5$. Before use, RNase (New England BioLabs, Ipswich, MA) was added to the buffer to a final concentration of $50 \mu \mathrm{g} \cdot \mathrm{mL}^{-1}$. For each heavenly bamboo cultivar, three leaf samples collected from three plants were analyzed.

Cereal rye (Secale cereal L. 'Daňkovské') $(2 \mathrm{C}$ nuclear DNA content $=16.19 \mathrm{pg})$ was used as an internal reference in the analysis. Young plants were grown in a greenhouse at the Gulf Coast Research and Education Center, and their leaves were cochopped with heavenly bamboo leaf tissue. The absolute nuclear DNA content of heavenly bamboo samples was calculated as described by Doležel et al. (2007) using the following formula: sample DNA content (pg) = 'Daňkovské' cereal rye DNA content $\times$ sample mean peak position/'Daňkovské' cereal rye mean peak position. The estimated DNA content of heavenly bamboo samples was compared with the DNA content of wild-type, 'Harbour Dwarf', and their diploid and tetraploid progeny to determine the ploidy level of samples. Wildtype and 'Harbour Dwarf' tetraploids were previously induced with colchicine treatments (Deng et al., 2011).

Experimental design and statistical analysis. The field experiments were conducted similarly in northern and southern Florida. A randomized complete block experimental design was used with nine heavenly bamboo cultivars placed in three-plant plots (except 'Alba' in two-plant plots) replicated three times (blocks). Visual quality was assessed every 12 weeks on each plant at both sites and presented with SE of northern and southern Florida means. Growth data were collected on each plant, subjected to analysis of variance (ANOVA), and significant means among cultivars separated by least significant difference at $P=0.05$ using SAS statistical software (Version 9.2 for Windows; SAS Institute, Cary, NC). Percentage data for the seed viability and germination studies were transformed by a square root arcsin before conducting an ANOVA. Transformed means were separated by a Duncan's multiple range test $(P=0.05)$ with untransformed cultivar means presented in Table 4 .

\section{Results}

Visual quality and growth. Visual quality varied by cultivar and site (Table 2; Fig. 2). In southern Florida, plant mortality occurred with 'Alba' ( $83 \%$ survival), 'Firehouse' (44\% survival), 'Firepower' (89\% survival), 'Gulf 


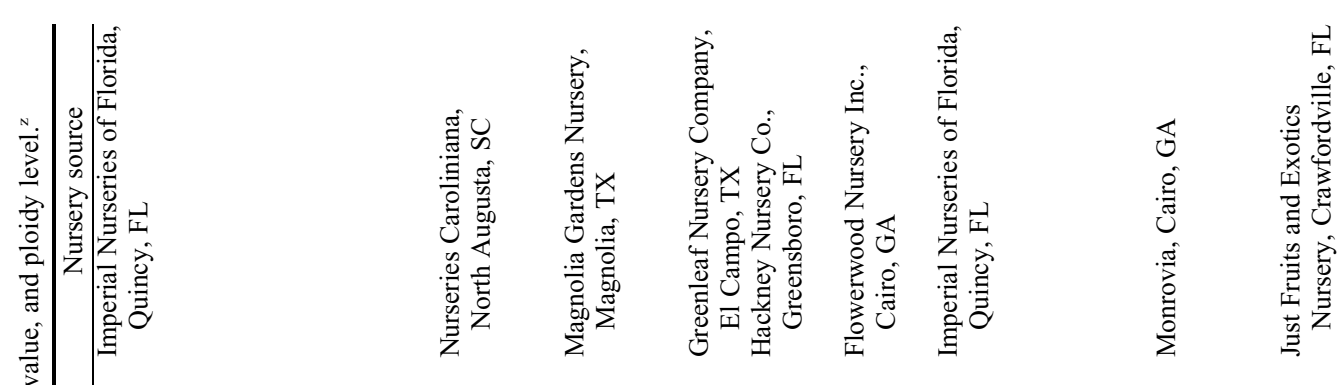

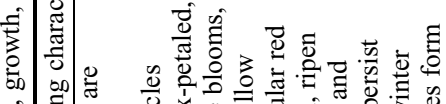

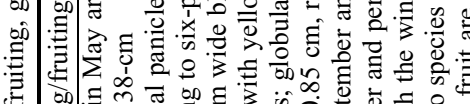

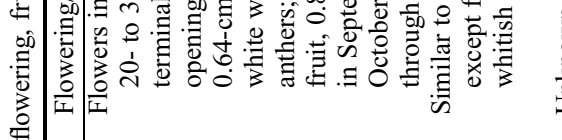

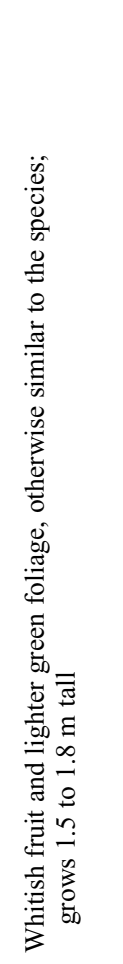

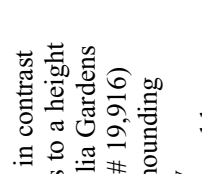

둘

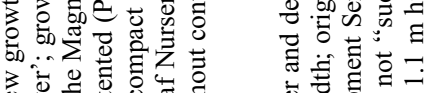

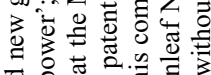

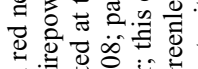

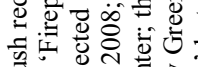

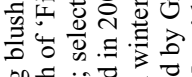

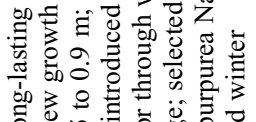

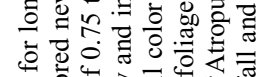

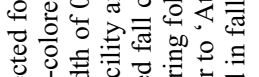

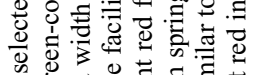

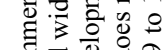

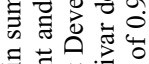

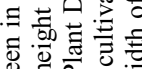

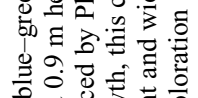

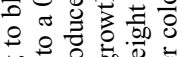

of

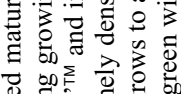

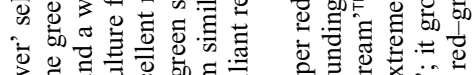

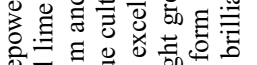

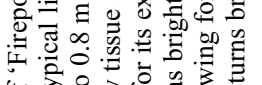

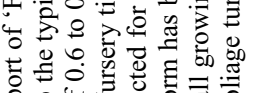

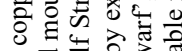

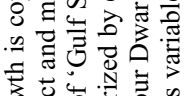

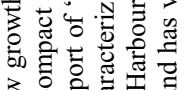

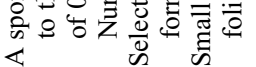

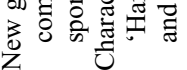

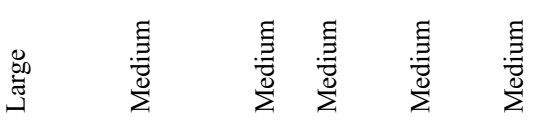

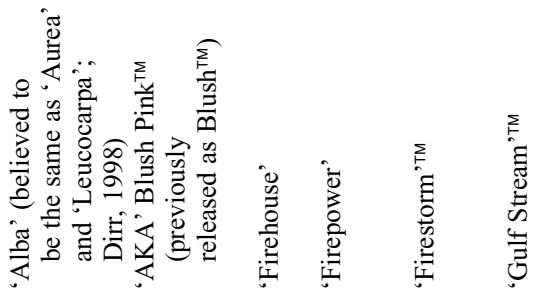


Stream' (89\% survival), and 'Monfar' (78\% survival) (Table 2). In northern Florida, plant mortality occurred with 'Alba' (83\% survival) and 'Firehouse' (67\% survival).

'AKA' and 'Firehouse' were selected from 'Firepower' for improved appearance. In southern Florida, 'AKA' demonstrated this improved appearance with visual quality ratings ranging from good to excellent (Fig. 2). In contrast, 'AKA' visual quality in northern Florida varied greatly with higher ratings corresponding to flushes of new growth or bright foliage coloration that occurred during cool weather and lower ratings associated with summer's higher temperatures and light intensity. 'Firepower' and 'Firehouse' generally had poor to fair visual quality ratings in northern Florida and fair ratings in southern Florida. Although 'Firepower' maintained a nice form throughout the study, lower rankings were attributed to the mottled color of the foliage because the brilliant red attributes were lost and never regained.

Southern Florida plantings of 'Firestorm' produced visual quality ratings greater than 'Gulf Stream', from which it was selected, whereas the opposite rankings occurred in northern Florida (Fig. 2). Indeed, after 1 year in northern Florida, 'Gulf Stream' and 'Monfar' displayed good to excellent visual quality attributable to dense growth, good foliage color, and tolerance of full sun conditions. Wild-type heavenly bamboo had fair to good visual quality ratings, whereas 'Alba', 'Firepower', and 'Moyer's Red' generally had fair visual quality ratings in both locations throughout the study. These visual quality assessments are of particular interest from an ornamental perspective, because heavenly bamboo is not as commonly used in southern Florida landscapes as it is in northern Florida landscapes (S.B. Wilson and G.W. Knox, personal observations), yet the majority of the taxa evaluated performed acceptably in either location.

Final plant height, width, and growth index varied by cultivar and site (Table 2 ). Wildtype, 'Alba' and 'Moyer's Red' are considered large cultivars (Table 1; Roethling et al., 2003) but did not reach this size category (height greater than $1.5 \mathrm{~m}$ ) by 144 weeks (Table 2). Plants grew less in southern Florida.

Flowering, fruit production, and seed viability. 'AKA', 'Firehouse', 'Firepower', and 'Firestorm' did not flower or fruit at either location (Table 3). All other selections flowered and fruited at both locations but not all plants within a selection flowered or fruited each year. The onset of flowering in Year 1 began in April or May (at planting or within 4 weeks after planting) in both locations (data not presented). Flowering in southern Florida generally began in April of Year 2 and May of Year 3 (although 'Alba' began flowering in March). Flowering in northern Florida generally occurred in May or June of Years 2 and 3, somewhat later than southern Florida as a result of the longer winter.

Flowering continued up to 12 weeks and was often simultaneous with fruiting that typically occurred 4 to 8 weeks later (data not presented). This information may be useful
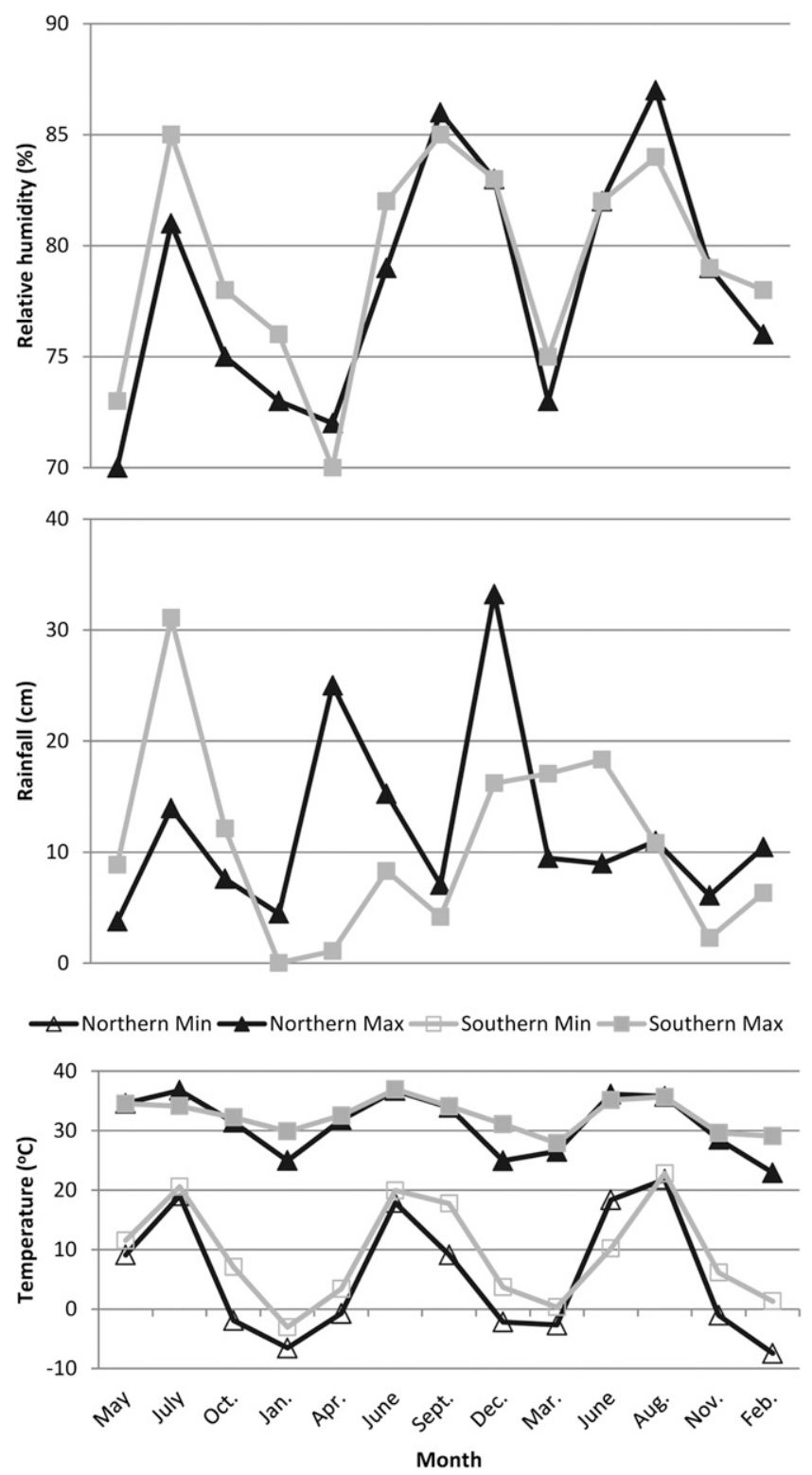

Fig. 1. Monthly average total rainfall, relative humidity and minimum and maximum air temperatures from planting date (May 2008) to last evaluation date (Feb. 2011) for Nandina domestica grown in northern $(-\triangle-)$ and southern $(-\square-)$ Florida.

Table 2. Plant height, width, growth index and survival of nine Nandina domestica selections grown for 144 weeks in northern (Quincy) and southern (Fort Pierce) Florida.

\begin{tabular}{|c|c|c|c|c|c|c|c|c|}
\hline \multirow[b]{2}{*}{ Selection } & \multicolumn{2}{|c|}{ Plant ht $(\mathrm{cm})$} & \multicolumn{2}{|c|}{ Plant width ${ }^{\mathrm{z}}(\mathrm{cm})$} & \multicolumn{2}{|c|}{ Growth index ${ }^{\mathrm{y}}(\mathrm{cm})$} & \multicolumn{2}{|c|}{ Survival (\%) } \\
\hline & Northern & Southern & Northern & Southern & Northern & Southern & Northern & Southern \\
\hline Wild-type & 113.2 & 45.1 & 89.7 & 38.7 & 97.6 & 40.9 & 100.0 & 100.0 \\
\hline Alba & 77.3 & 54.7 & 64.6 & 54.8 & 68.8 & 54.7 & 83.3 & 83.3 \\
\hline AKA & 40.9 & 27.9 & 47.3 & 33.8 & 45.2 & 31.9 & 100.0 & 100.0 \\
\hline Firehouse & 31.6 & 29.2 & 35.9 & 22.2 & 34.5 & 24.5 & 66.7 & 44.4 \\
\hline Firepower & 49.8 & 39.3 & 42.4 & 24.6 & 44.9 & 29.5 & 100.0 & 88.9 \\
\hline Firestorm & 38.4 & 32.2 & 39.0 & 28.8 & 38.8 & 29.9 & 100.0 & 100.0 \\
\hline Gulf Stream & 91.6 & 46.5 & 91.4 & 35.5 & 91.4 & 39.1 & 100.0 & 88.9 \\
\hline Monfar & 79.7 & 47.6 & 76.2 & 33.2 & 77.4 & 38.0 & 100.0 & 77.8 \\
\hline Moyer's Red & 90.9 & 65.6 & 74.7 & 42.0 & 80.1 & 49.9 & 100.0 & 100.0 \\
\hline $\operatorname{LSD}(0.05)^{\mathrm{x}}$ & 15.7 & 7.8 & 14.2 & 13.1 & 14.4 & 10.1 & $\mathrm{NS}^{\mathrm{w}}$ & 0.3 \\
\hline
\end{tabular}

${ }^{\mathrm{z}}$ Reported as the average of two perpendicular plant widths.

${ }^{\mathrm{y}}$ Growth index calculated by obtaining the average of the plant height and two perpendicular widths.

${ }^{x}$ Least significant difference at $P=0.05$ level.

wonsignificant at $P=0.05$ level.

because Perrins et al. (1992) reported that the length of the flowering period was longer in weedy species as compared with non-weedy species. Also, long flowering periods may allow greater accessibility to pollinators and a greater chance of seed set (Raulston, 1984). 

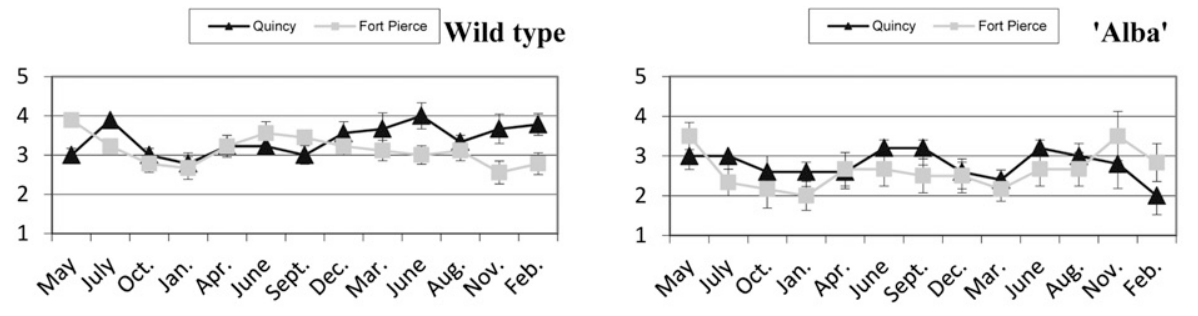

$\rightarrow$ Quincy $\longrightarrow$ Fort Pierce 'AKA'

$\rightarrow$ Quincy $\rightarrow-$ Fort Pierce 'Firehouse'
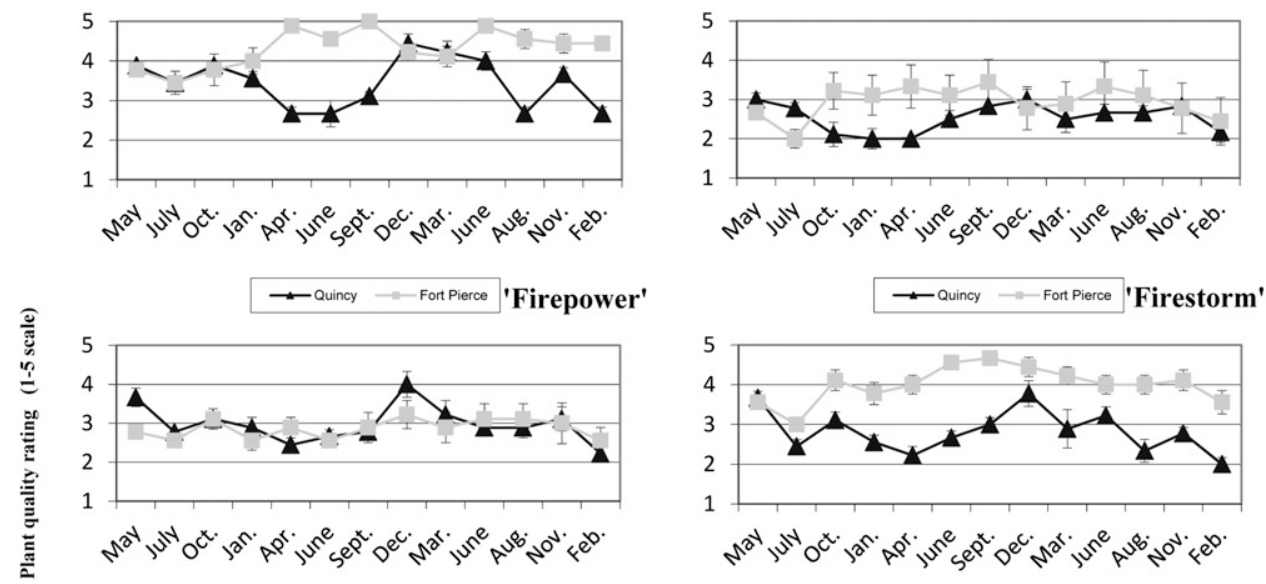

'Gulf Stream'
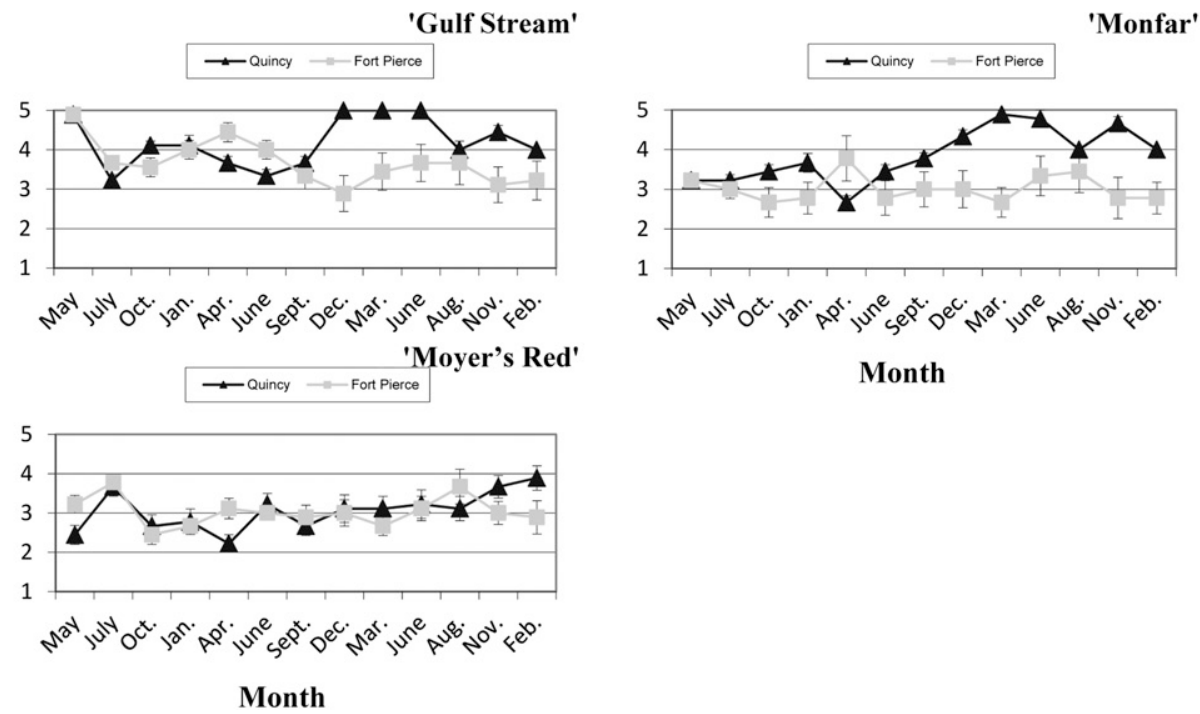

Fig. 2. Plant quality rating ( 1 to 5 scale where $1=$ poor and $5=$ excellent $)$ of nine Nandina domestica selections grown for 144 weeks in northern $(-\triangle-)$ and southern (- $\square$ - Florida. Data shown is the average of nine replicates.

Table 3. Final fruit and seed counts (average per fruiting plant) of nine Nandina domestica selections after being grown in northern Florida (Quincy) and southern Florida (Fort Pierce) for 144 weeks.

\begin{tabular}{|c|c|c|c|c|}
\hline \multirow[b]{2}{*}{ Selection } & \multicolumn{2}{|c|}{ Avg fruit (no.) $(\mathrm{n}=9)^{\mathrm{z}}$} & \multicolumn{2}{|c|}{ Avg seed (no.) $(\mathrm{n}=9)^{\mathrm{y}}$} \\
\hline & Northern Florida & Southern Florida & Northern Florida & Southern Florida \\
\hline Wild-type & 1274 & 134 & 1813 & 211 \\
\hline Alba & 411 & 35 & 697 & 68 \\
\hline AKA & 0 & 0 & 0 & 0 \\
\hline Firehouse & 0 & 0 & 0 & 0 \\
\hline Firepower & 0 & 0 & 0 & 0 \\
\hline Firestorm & 0 & 0 & 0 & 0 \\
\hline Gulf Stream & 141 & 5 & 175 & 6 \\
\hline Monfar & 80 & 4 & 94 & 5 \\
\hline Moyer's Red & 484 & 67 & 785 & 109 \\
\hline
\end{tabular}

${ }^{\mathrm{z}}$ Fruit collected November and December of 2010.

${ }^{\mathrm{y}}$ Fruit can contain between one and four seeds, although they usually contain one or two seeds.

Greatest fruiting was observed for the wild-type selection followed by 'Moyer's Red', 'Alba', 'Gulf Stream', and 'Monfar', respectively (Table 3 ). Typically, dwarf and medium-sized cultivars produce fewer fruit than large-sized plants (Knox and Wilson,
2006), limiting the potential for distribution. It was also observed that large-sized heavenly bamboo typically produced larger seeds than smaller sized cultivars (data not presented). Large seeds contained within the fleshy fruit of some woody species can augment predation, distribution, and establishment (McPherson, 1987). Although minimal, it should be noted that reported fruit yield was conservative in that fruit occasionally fell before maturing, and panicles missing fruit were observed, particularly on smaller cultivars. Fruit drop or abortion can be caused by pollination problems, maternal resource limitations, climatic conditions, and pest or physical damage (Banelos and Obeso, 2005; Shiell et al., 2002), but evaluating the causes of fruit loss was not within the scope of this study. 
All taxa that fruited produced more fruit in northern Florida than southern Florida (Table 3). This supports conclusions made by the IFAS assessment, which states the wild-type form is invasive and not eligible for use in northern or central Florida, but it may be recommended in southern Florida if managed to prevent escape (IFAS Invasive Plant Working Group, 2013). In an earlier study, large-sized group cultivars Compacta and Monum produced fruit with viable seed in quantities comparable to the wild-type selection (Knox and Wilson, 2006) and could therefore have a greater likelihood of escaping into natural areas as compared with medium-sized or dwarf-sized cultivars that produced few if any fruit.

Pre-germination seed viability was similar among fruiting cultivars, ranging from $69 \%$ ('Alba') to $86.5 \%$ (wild-type) (Table 4). This is comparable to the $85 \%$ seed viability previously reported for the wild-type (Knox and Wilson, 2006). In addition, 'Gulf Stream', 'Monfar', and 'Moyer's Red' had 83.0\%, $82.5 \%$, and $74.5 \%$ pre-germination seed viability, respectively. Seed germination was far less than pre-germination viability and postgermination viability tests confirmed that $47.5 \%$ to $77.5 \%$ of seeds were still dormant after the 60-d germination period (Table 4). A short period between the onset of flowering and seed germination has been associated with many invasive species (Pyšek and Richardson, 2007; Rejmánek and Richardson, 1996; Wilson et al., 2012). This however is not apparent for heavenly bamboo. The rudimentary embryo characteristic of heavenly bamboo seed requires considerable time to develop before germination and some embryo abortion is likely (Dehgan, 1984). Typically, regardless of the planting date, germination tends to be delayed until fall (Gilman, 1999). The seeds from this study were subjected to standard seed testing laboratory conditions (petri dishes, 8-h photoperiod, $30 / 20^{\circ} \mathrm{C}$ ). Growers typically clean seed, place in flats containing a soilless media, and place under natural conditions outside until germination (Stewart Chandler, Monrovia, Cairo, GA, personal communication). Interestingly, 'Gulf Stream' and 'Monfar' had less dormancy and greater germination than the other cultivars (Table 4 ), yet produced substantially less fruit than the wild-type, 'Alba', and 'Moyer's Red' (Table 3).

Nuclear DNA content and ploidy level. Although many of the leaf samples collected in this study were very mature, highly leathery, and pigmented, they produced decent histograms of fluorescence intensity with acceptable $\mathrm{CV}(1.44 \%$ to $4.25 \%)$. These $\mathrm{CV}$ values suggest that the nuclear extraction and staining buffers used worked well with nandina samples. Two sources of wild-type diploid samples were used: three large seed-grown plants (Imperial Nurseries of Florida, Quincy, FL) and four young seedlings. The nuclear DNA content of the three large wild-type diploid plants was $4.52 \mathrm{pg}, 7.9 \%$ higher than the average nuclear DNA content of the four seedlings. Similarly, two sources of 'Harbour Dwarf' leaf samples were used. Nevertheless, the nuclear DNA content of asexually propagated 'Harbour Dwarf' plants and 'Harbour Dwarf' seedlings was very close (4.18 vs. $4.31 \mathrm{pg} / 2 \mathrm{C}$ ) with the difference falling within the $\mathrm{CV}$ range observed in the flow cytometry analysis. The nuclear DNA content of the eight selections was 4.14 to $4.54 \mathrm{pg} / 2 \mathrm{C}$, very similar to the nuclear DNA content of wildtype diploid and 'Harbour Dwarf' (4.18 to $4.52 \mathrm{pg} / 2 \mathrm{C}$ ), suggesting that these selections were all diploids (Table 5).

\section{Discussion}

It should be noted that the current study was conducted in full sun, field trial conditions, which may be less typical of a home landscape. The wild-type form of heavenly bamboo is considered a shade-tolerant species occasionally escaping in wet, disturbed hammocks of Florida (Wunderlin and Hansen, 2008). Observationally, heavenly bamboo cultivars would likely have better visual quality in Florida under partial shade because full sun appeared to stress some selections although plants were irrigated as needed. Whereas establishment, growth, and reproduction are expected to vary under shade and full sun environments, Cherry (2002) found heavenly bamboo to have a high physiological acclimation ability at varying light levels. This suggests that heavenly bamboo has the potential to acclimate well to high light conditions found in northern or southern Florida. This can be significant, because the ability to capture and efficiently use light can greatly contribute to a plant's competitive ability (Baruch and Goldstein, 1999; Rejmánek and Richardson, 1996).

Temperature likely affected fruit formation at the two Florida sites, because northern Florida has more chilling hours throughout the winter (USDA, 2012). This is consistent with findings from other invasive temperate species in Florida, because Wilson et al. (2014) reported that glossy privet (Ligustrum lucidum), chinese privet (Ligustrum sinense), and japanese privet (Ligustrum japonicum) collectively produced over 600 times more fruit in northern Florida than southern Florida. Differences in fruit formation between the two Florida sites also may relate to plant growth. Although plants were fertilized and irrigated similarly at both sites, plants grew larger and fruited more in northern Florida.

Previously we observed significant differences among heavenly bamboo cultivars

Table 4. Percent viability and germination of seed collected from nine Nandina domestica selections grown in northern Florida. ${ }^{\mathrm{z}}$

\begin{tabular}{lccc}
\hline Selection & Pre-germination viability $(\%)$ & Germination after $60 \mathrm{~d}^{\mathrm{y}}(\%)$ & Dormant $(\%)$ \\
\hline Wild-type & $86.5 \mathrm{a}^{\mathrm{x}}$ & $6.8 \mathrm{bc}$ & $70.8 \mathrm{a}$ \\
Alba & $69.0 \mathrm{a}$ & $12.5 \mathrm{~b}$ & $74.5 \mathrm{a}$ \\
AKA & $-{ }^{\mathrm{w}}$ & $-{ }^{\mathrm{w}}$ & $-{ }^{\mathrm{w}}$ \\
Firehouse & $-{ }^{\mathrm{w}}$ & $-{ }^{\mathrm{w}}$ & $-{ }^{\mathrm{w}}$ \\
Firepower & $-{ }^{\mathrm{w}}$ & $-{ }^{\mathrm{w}}$ & ${ }^{\mathrm{w}}$ \\
Firestorm & $83.0 \mathrm{a}$ & $31.8 \mathrm{a}$ & $47.5 \mathrm{~b}$ \\
Gulf Stream & $82.5 \mathrm{a}$ & $27.8 \mathrm{a}$ & $54.5 \mathrm{~b}$ \\
Monfar & $74.5 \mathrm{a}$ & $5.5 \mathrm{c}$ & $77.5 \mathrm{a}$ \\
Moyer's Red & $8-\mathrm{c}$ &
\end{tabular}

${ }^{\mathrm{z}}$ Seeds were subjected to an 8 -h photoperiod at $30^{\circ} \mathrm{C}$ followed by $16 \mathrm{~h}$ darkness at $20^{\circ} \mathrm{C}$. Performed on a subset of 200 seed (two replications of 100).

y Performed on 400 seed (four replications of 100). Remaining seeds that did not germinate were subjected to viability tests and used to calculate dormancy.

${ }^{x}$ Mean separation was conducted by Duncan's multiple range test on transformed means. Different lowercase letters within columns are significantly different $(P=0.05)$.

${ }^{\mathrm{w}}$ Cultivar did not produce fruit within the timeframe of the study.

Table 5. Nuclear DNA content of nine Nandina domestica selections based on flow cytometry analysis and inferred ploidy level. ${ }^{\mathrm{z}}$

\begin{tabular}{|c|c|c|c|c|}
\hline Selection & Samples (no.) & Collection site & Ploidy level & $\begin{array}{c}\text { Nuclear DNA } \\
\text { content } \pm \mathrm{SD}(\mathrm{pg} / 2 \mathrm{C})\end{array}$ \\
\hline Wild-type & $-\mathrm{y}$ & $-\mathrm{y}$ & $2 x$ & $4.4^{y}$ \\
\hline Wild-type & 3 & Northern & $2 x$ & $4.52 \pm 0.13$ \\
\hline Wild-type seedling & 4 & Southwestern & $2 x$ & $4.19 \pm 0.17$ \\
\hline Harbour Dwarf & 3 & Northern & $2 x$ & $4.18 \pm 0.13$ \\
\hline $\begin{array}{l}\text { Harbour Dwarf } \\
\text { seedling }\end{array}$ & 4 & Southwestern & $2 x$ & $4.31 \pm 0.16$ \\
\hline Alba & 3 & Southern & $2 x$ & $4.25 \pm 0.13$ \\
\hline AKA & 3 & Northern & $2 x$ & $4.29 \pm 0.11$ \\
\hline Firehouse & 3 & Northern & $2 x$ & $4.22 \pm 0.15$ \\
\hline Firepower & 3 & Northern & $2 x$ & $4.24 \pm 0.06$ \\
\hline Firestorm & 3 & Northern & $2 x$ & $4.28 \pm 0.09$ \\
\hline Gulf Stream & 3 & Northern & $2 x$ & $4.14 \pm 0.10$ \\
\hline Monfar & 3 & Northern & $2 x$ & $4.33 \pm 0.19$ \\
\hline Moyer's Red & 3 & Southern & $2 x$ & $4.54 \pm 0.13$ \\
\hline
\end{tabular}

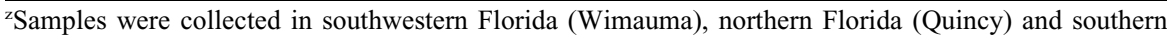
Florida (Fort Pierce).

${ }^{\mathrm{y}}$ Reported by Bharathan et al. (1994). Source of plant material or cultivar, sample size, and sD unknown. 
in fruiting and seed germination (Knox and Wilson, 2006). Again, large differences in fruiting capacity were noted in this study among nine heavenly bamboo selections. None of the plants of 'AKA', 'Firehouse', 'Firepower', or 'Firestorm' produced any fruit in either northern or southern Florida (Table 3). Prolific fruiting was observed for the wild-type form as well as 'Alba' and 'Moyer's Red' in this study. 'Gulf Stream' and 'Monfar' produced less than $10 \%$ of fruit yield of the wild-type form in northern Florida and less than 3\% of fruit yield of the wild-type form in southern Florida. In addition, fruit of these two cultivars were smaller in size and most was found within the canopy of foliage, reducing fruit visibility and perhaps predation.

Developing non-fruiting heavenly bamboo cultivars will be extremely valuable for curtailing the invasive potential of heavenly bamboo in the southeastern United States. Understanding the genetic cause(s) of the non-fruiting trait in the existing heavenly bamboo cultivars may lead to effective breeding strategies for developing new nonfruiting cultivars. Deng et al. (2011) reported that induced tetraploid heavenly bamboo flowered similarly as their diploid counterparts but did not set or set few fruit, which prompted us to investigate the ploidy level of these non-fruiting cultivars. Our nuclear DNA content and ploidy analysis results showed that all eight heavenly bamboo cultivars were diploids; thus, tetraploidy was not the genetic cause of the non-fruiting trait in 'AKA', 'Firehouse', 'Firepower', or 'Firestorm'.

'Firepower' has been reported previously as a non-fruiting selection (Knox and Wilson, 2006). Two selections in this study, 'AKA' and 'Firehouse', are sports of 'Firepower', and they also did not set fruit. These observations suggest that the non-fruiting trait in 'Firepower' may be transmissible. Should this be true with other non-fruiting cultivars, it may suggest an effective strategy for obtaining new non-fruiting, non-invasive cultivars. Another new, allegedly non-fruiting cultivar, Kaydee Atomic Fireball, has a dwarf habit but originated as a sport of the medium-sized 'Firepower' (Knox, 2012). Conceivably, in future breeding research, buds of existing non-fruiting cultivars could be exposed to mutagenic treatments such as gamma ray irradiation to induce new mutants with desirable foliage colors and/or plant size and growth habit.

'Firestorm' was derived from 'Gulf Stream' and 'Gulf Stream' was a sport of 'Compacta'. We observed dramatic differences among these three selections in fruiting. Plants of 'Compacta' were highly prolific in fruiting in northern, central, and southern Florida, whereas plants of 'Gulf Stream' were much less prolific in fruiting, especially in central and southern Florida (Knox and Wilson, 2006; Zhanao Deng, unpublished data). In this study, plants of 'Firestorm' did not fruit at all. The progressive reduction in fruiting capacity from 'Compacta' to 'Firestorm' may suggest good potential for selecting new non-fruiting cul- tivars even from highly prolific existing cultivars.

Advances in breeding technologies to introduce new and novel cultivars have increased significantly during the last decade (Drew et al., 2010). Recent breeding initiatives have included sterility for new cultivar releases of wild-type species that have invasive potential (Czarnecki et al., 2012; Freyre et al., 2012; Knight et al., 2011; Ranney, 2004). Results from this research will conceivably guide the horticulture industry, research breeding efforts, land managers, and consumer awareness for plant selection, population prevention, and control.

In summary, performance, flowering, and fruiting varied among heavenly bamboo cultivars and planting location. Greater plant survival and growth with heavier fruiting was observed in northern Florida than in southern Florida. Above average visual quality rankings, good survival, and limited or absent fruit production of 'AKA', 'Firestorm', and 'Gulf Stream' warrant wider landscape use of these selections in the southern Florida landscape. In northern Florida, where the wildtype has escaped and is considered invasive, 'Firepower', 'Firehouse', and 'Firestorm' did not fruit but were not as attractive as 'Gulf Stream' and 'Monfar' (that had excellent survival, good year-round appearance, and limited fruit production). 'AKA' did not fruit and had better winter performance than 'Firepower' and its derivatives. This may be an acceptable alternative for the nursery industry in both northern and southern Florida.

\section{Literature Cited}

Banelos, M.J. and J. Obeso. 2005. How is fruit production regulated in the dioecious fleshyfruited shrub Rhamnus alpinus? Basic Appl. Ecol. 6:249-259.

Baruch, Z. and G. Goldstein. 1999. Leaf construction cost, nutrient concentration, and net $\mathrm{CO}_{2}$ assimilation of native and invasive species in Hawaii. Oecol. 121:183-192.

Bharathan, G., G. Lambert, and D.W. Galbraith. 1994. Nuclear DNA content of monocotyledons and related taxa. Amer. J. Bot. 81:381-386.

Cherry, H.M. 2002. Ecophysiology and control of Nandina domestica Thunb. MS thesis, University of Florida, Gainesville, FL.

Czarnecki, D.M., S.B. Wilson, G.W. Knox, R. Freyre, and Z. Deng. 2012. UF-T3 and UF-T4: Two sterile Lantana camara cultivars. HortScience 47:132-137.

Dehgan, B. 1984. Germination of Nandina domestica seed as influenced by GA3 and stratification. Proc. Fla. State Hort. Soc. 97:311-313.

Dehnen-Schmutz, K., J. Touza, C. Perrings, and M. Williamson. 2007. A century of the ornamental plant trade and its impact on invasion success. Divers. Distrib. 13:527-534.

Deng, Z., S. Smith, G.W. Knox, and S.B. Wilson. 2011. Induction and characterization of tetraploids in nandina. HortScience 46:S169 [Abstract].

Dirr, M.A. 1998. Manual of woody landscape plants. Their identification, ornamental characteristics, culture, propagation and uses. $5^{\text {th }} \mathrm{Ed}$. Stipes Publ., Champaign, IL.

Dirr, M.A. 2002. Dirr's trees and shrubs for warm climates. Timber Press, Portland OR.

Doležel, J., J. Greilhuber, and J. Suda. 2007. Estimation of nuclear DNA content in plants using flow cytometry. Nat. Protoc. 2:22332244.

Drew, J., N. Anderson, and D. Andow. 2010. Conundrums of a complex vector for invasive species control: A detailed examination of the horticultural industry. Biol. Invasions 12:28372851.

Florida Exotic Pest Plant Council. 2013. Florida EPPC's 2013 invasive plant species list. 5 Jan. 2014. <http://www.fleppc.org/list/13list.html>.

Freyre, R., A. Moseley, S.B. Wilson, and G.W. Knox. 2012. Fruitless Ruellia simplex R10-102 ('Mayan Purple') and R10-108 ('Mayan White'). HortScience 47:1808-1814.

Gilman, E.F. 1999. Nandina domestica. University of Florida Institute of Food and Agricultural Sciences (IFAS) Fact Sheet FPS-421 5 June 2013. <http://edis.ifas.ufl.edu/FP421>.

Hodges, A.W., T.J. Stevens, M. Rahmani, and H. Khachatryan. 2011. Economic contributions of the Florida environmental horticulture industry in 2010. Univ. Florida Food Resource Econ. Rpt. 12 Oct. 2013. <http://www. fred.ifas.ufl.edu/economic-impact-analysis/pdf/ Economic_Contributions_Florida_Environmental_ Horticulture_Industry_2010.pdf $>$.

IFAS Invasive Plant Working Group. 2013. IFAS Assessment of non-native plants in Florida's natural areas. 1 Oct. 2013. <http://plants.ifas. ufl.edu/assessment/conclusions.html>.

Knight, T.M., K. Havens, and P. Vitt. 2011. Will the use of less fecund cultivars reduce the invasiveness of perennial plants? Bioscience 61:816-822.

Knox, G.W. 2012. Noninvasive nandina cultivars for the green industry. Center Applied Nursery Res. Rpt. 29 Dec. 2013. <http://canr.org/pastprojects/ 2012005>.

Knox, G.W. and S.B. Wilson. 2006. Evaluating north and south Florida landscape performance and fruiting of ten cultivars and a wildtype selection of Nandina domestica, a potentially invasive shrub. J. Environ. Hort. 24:137-142.

Knox, G.W. and S.B. Wilson. 2009. 'Firepower' nandina (Nandina domestica): A noninvasive nandina for Florida. University of Florida Institute of Food and Agricultural Sciences (IFAS) Extension Publication, ENH1116/ EP381. 20 Jan. 2014. <http://edis.ifas.ufl.edu/ EP381>.

Knox, G.W. and S.B. Wilson. 2010. 'Harbour Dwarf' nandina (Nandina domestica): Noninvasive in south Florida and recommended with caution in central and north Florida. University of Florida Institute of Food and Agricultural Sciences (IFAS) Extension Publication, ENH1158/EP418. 20 Jan. 2014. <http://edis.ifas. ufl.edu/ep418>.

Langeland, K.A., H.M. Cherry, C.M. McCormick, and K.A. Craddock Burks. 2008. Identification and biology of non-native plants in Florida's natural areas. $2^{\text {nd }} E d$. University of Florida, IFAS Communication Services, Gainesville, FL.

McPherson, J.M. 1987. A field study of winter fruit preferences of cedar waxwings. The Condor 89:293-306.

Parker, C., B.P. Caton, and L. Fowler. 2007. Ranking nonindigenous weed species by their potential to invade the United States. Weed Sci. 55:386-397.

Pemberton, R.W. and H. Liu. 2009. Marketing time predicts naturalization of horticultural plants. Ecology 90:69-80.

Perrins, J., M. Williamson, and A. Fitter. 1992. Do annual weeds have predictable characters? Acta Oecol. 13:517-533.

Peters, J. 2000. Tetrazolium testing handbook, contribution No. 29 to the handbook on seed 
testing. Association of Official Seed Analysts. Las Cruces, NM.

Pyšek, P. and D.M. Richardson. 2007. Traits associated with invasiveness in alien plants: Where do we stand? Ecological studies, p. 97-193. In: Nentwig, W. (ed.). Biological invasions. Springer-Verlag, Berlin/Heidelberg, Germany.

Ranney, T.G. 2004. Population control: Developing non-invasive nursery crops. Combined Proc. Intl. Plant Propagators Soc. 54:604-607.

Raulston, J.C. 1984. Nandina domestica cultivars in the NCSU Arboretum. Friends of the Arboretum Newsletter. 16 June 2005. <http://www.ncsu.edu/ jcraulstonarboretum/publications/newsletters/ ncsu_arboretum_newsletters/News11_84-12.html $>$.

Reichard, S.H. and C.W. Hamilton. 1997. Predicting invasions of woody plants introduced into North America. Conserv. Biol. 11:193-203.
Rejmánek, M. and D.M. Richardson. 1996. What attributes makes one plant species more invasive? Ecology 77:1655-1661.

Roethling, J.L., C.T. Glenn, and F.T. Lasseigne. 2003. Long-term evaluation of Nandina domestica cultivars at the JC Raulston Arboretum. Proc. South. Nurs. Res. Conf. 48:373378.

Shiell, K.J., R.G. St-Pierre, and A.M. Zatylny. 2002. Timing, magnitude and causes of flower and immature fruit loss in pin cherry and choke cherry. Can. J. Plant Sci. 82:157-164.

U.S. Department of Agriculture. 2012. About the USDA hardiness zones. 25 May 2013. <http:// plants.usda.gov/hardiness.html>.

U.S. Department of Agriculture. 2013. The PLANTS database. 30 Nov. 2013. <http://plants.usda.gov/ core/profile?symbol=NADO $>$.
Wilson, S.B., G.W. Knox, Z. Deng, and R. Freyre. 2012. Characterizing the invasive potential of ornamental plants. Acta Hort. 937:11831192.

Wilson, S.B., G.W. Knox, K.L. Nolan, and J. Aldrich. 2014. Landscape performance and fruiting of 12 privet selections grown in northern and southern Florida. HortTechnology 24:1-8.

Williamson, M.H. and A. Fitter. 1996. The characters of successful invaders. Biol. Conserv. 78:163-170.

Wirth, F.F., K.J. Davis, and S.B. Wilson. 2004. Florida nursery sales and economic impacts of 14 potentially invasive landscape plant species. J. Environ. Hort. 22:12-16.

Wunderlin, R.P. and B.F. Hansen. 2008. Atlas of Florida vascular plants. 1 Oct. 2013. <http:// www.plantatlas.usf.edu/>. 